\title{
KARAKTERISTIK KWETIAU DARI TEPUNG BERAS MERAH (Oryza sativa)
}

\author{
[Characteristics of Kwetiau Made of Red Rice (Oryza sativa) Flour] \\ Kiki Yuliati, Merynda Indriyani Syafutri*, Christian Madona \\ Program Studi Teknologi Hasil Pertanian, Jurusan Teknologi Pertanian \\ Fakultas Pertanian, Universitas Sriwijaya, Indralaya, Ogan Ilir, Sumatera Selatan \\ *email: misyafutri@gmail.com / merynda@fp.unsri.ac.id \\ Diterima 27 Januari 2020 / Disetujui 06 Juli 2020
}

\begin{abstract}
The objective of this research was to analyze the characteristics of kwetiau made of red rice flour with binding agents addition and soaking time of red rice. This research used a Factorial Completely Randomized Design with two factors. The first factor was types of binding agent (tapioca, glutinous rice flour and sago), and the second factor was the soaking time (1.5 hours and 3 hours). The observed parameters were physical (color, texture, elongation), chemical (moisture, ash, crude fiber, total anthocyanin content, and sensory characteristics (flavor, color, texture, taste). The results showed that the types of binding agent had significant effects on texture, elongation, and moisture content, while the soaking time had significant effects on color $\left(L^{*}, a^{*}, b^{*}\right)$, texture, moisture and ash content. Interaction of binding agent and soaking time had significant effects on texture and moisture content. Based on sensory characteristics and moisture content (Indonesian National Standard No. 2987-2015), the best treatment was kwetiau A1B1 (tapioca as binding agent; 1.5 hours of soaking time).
\end{abstract}

Keywords: binding agent, kwetiau, red rice flour, soaking time

\section{ABSTRAK}

Penelitian ini bertujuan untuk menganalisa karakteristik kwetiau dari tepung beras merah dengan penambahan beberapa jenis bahan perekat dan lama perendaman beras merah. Penelitian menggunakan Rancangan Acak Lengkap faktorial dengan dua faktor perlakuan, yaitu jenis bahan perekat (tapioka, tepung beras ketan, dan sagu) dan lama perendaman beras merah (1,5 jam dan 3 jam). Parameter yang diamati adalah karakteristik fisik (warna, kekerasan, elongasi), kimia (air, abu, serat kasar, total antosianin), dan sensoris (flavor, warna, tekstur, rasa). Hasil penelitian menunjukkan bahwa jenis bahan perekat berpengaruh nyata terhadap kekerasan, elongasi dan kadar air, sedangkan lama perendaman berpengaruh nyata terhadap warna $\left(L^{*}, a^{*}, b^{*}\right)$, tekstur, elongasi, kadar air dan abu. Interaksi antara jenis bahan perekat dan lama perendaman berpengaruh nyata terhadap tekstur dan kadar air kwetiau tepung beras merah. Perlakuan terbaik ditentukan berdasarkan karakteristik sensoris dan parameter kadar air (SNI 2987-2015), perlakuan terbaik adalah kwetiau A1B1 (bahan perekat tapioka; lama perendaman beras merah 1,5 jam).

Kata kunci: bahan perekat, kwetiau, lama perendaman, tepung beras merah

\section{PENDAHULUAN}

Kwetiau merupakan produk pangan yang cukup populer di kalangan keturunan Tionghoa dan juga digemari oleh masyarakat Indonesia (Mutters dan Thompson, 2009). Kwetiau memiliki bentuk seperti mi yang warnanya putih bening dengan bentuk pipih dan lebar (Hormdok dan Noomhorm, 2007). Kwetiau digolongkan menjadi dua golongan, yaitu: kwetiau basah yang memiliki kandungan air cukup tinggi, cepat rusak, dan bertahan sehari jika tidak dimasukkan ke dalam lemari pendingin, dan 2) kwetiau kering yang dapat bertahan lama jika dikemas dalam kedap udara (Fadiati et al., 2009). Kwetiau atau rice noodles adalah salah satu variasi dari produk mi yang berbasis tepung beras, sedangkan mi pada umumnya terbuat dari tepung terigu yang tinggi gluten ( $\mathrm{Fu}$, 2008). Menurut Tanzil (2012), jenis beras di Indonesia yang cocok digunakan untuk pembuatan kwetiau adalah beras IR 64, karena jenis beras ini memiliki kadar amilosa yang sedang.

Tepung beras untuk kwetiau diproses dari beras giling yang telah disosoh. Penyosohan beras giling merupakan proses 
menghilangkan lapisan kulit ari dan lembaga beras. Kehilangan lapisan pericarp, aleuron, embrio dan endosperm membuat beras giling mengalami penurunan banyak zat gizi, terutama protein dan mineralnya (Askanovi, 2011; Nugraha, 1996; Widowati, 2001). Setiap $100 \mathrm{~g}$ beras giling mengandung $7,50 \mathrm{~g}$ protein, 2,68 g lemak, mineral utama yang terdiri 33,00 mg kalsium dan 143,00 mg magnesium dan $1,27 \mathrm{~g}$ mineral lainya, sedangkan $100 \mathrm{~g}$ beras sosoh mengandung 6,61 g protein, 0,58 g lemak, mineral utama yang terdiri $9,00 \mathrm{mg}$ kalsium dan $35,00 \mathrm{mg}$ magnesium dan $0,58 \mathrm{~g}$ mineral lainya (USDA, 2010).

Penggunaan beras merah dalam pembuatan kwetiau merupakan salah satu cara untuk meningkatkan kesukaan atau penerimaan terhadap beras merah, dan meningkatkan kandungan gizi kwetiau. Beras merah merupakan biji dari tanaman jenis padi-padian yang berwarna kemerahan. Kulit ari beras merah ini kaya akan kandungan minyak alami dan serat (Santika dan Rozakurniati, 2010). Lemak esensial sangat dibutuhkan untuk perkembangan otak anak, menurunkan kolestrol, dan juga resiko penyakit jantung (Fibriyanti, 2012). Beras merah juga mengandung vitamin B (Astawan, 2012), dan sejumlah komponen bioaktif seperti pigmen yang memberikan warna pada beras merah dan senyawa flavonoid yang dapat berperan sebagai antioksidan (Fibriyanti, 2012). Kapasitas antioksidan beras merah sebesar 6,08 mg Ascorbic acid Equivalent Antioxidant Capacity (AEAC) /100 $\mathrm{g}$ berat kering (Thoif, 2014). Setiap $100 \mathrm{~g}$ beras merah mengandung $14,38 \%$ air, $1,18 \%$ abu, 9,16\% protein, 2,50\% lemak, $3,97 \%$ serat kasar, $29,44 \%$ amilosa, $40,58 \%$ amilopektin, 70,03\% pati, dan 488,65 mg $\beta-$ karoten (Hernawan dan Meylani, 2016). Salah satu upaya untuk memudahkan pemanfaatan beras merah dalam pembuatan kwetiau adalah dengan cara mengolahnya menjadi tepung.

Beras dapat diberi perlakuan sebelum dihaluskan menjadi tepung. Salah satu perlakuan tersebut adalah proses perendaman dengan air. Perendaman ini biasa dilakukan selama dua sampai enam jam (Hasbullah dan Riskia, 2013). Menurut Chiang dan Yeh (2002) dalam Supriyadi (2012), saat proses perendaman struktur fisik beras melonggar dan melunak akibat hidrasi sehingga menghasilkan partikel tepung yang halus dengan kerusakan pati yang sedikit. Semakin lama waktu perendaman beras maka waktu yang diperlukan pada saat proses penggilingan semakin cepat, sehingga kerusakan pati yang diakibatkan oleh pemanasan dan gesekan pada saat penggilingan semakin sedikit. Jumlah kerusakan pati berbanding terbalik dengan daerah kristal amilosa yang tersisa pada granula pati. Semakin rendah struktur kristalin pada granula maka semakin cepat granula pati akan mengalami proses gelatinisasi (Chen et al., 1999; Suksomboon dan Naivikul, 2006). Granula yang mengalami proses gelatinisasi lebih cepat akan lebih cepat pula mengalami proses retrogradasi ketika suhu turun (Indriyani et al., 2013). Beras merah mengandung 29,44\% amilosa (Hernawan et al., 2016). Kandungan amilosa yang tinggi menyebabkan proses retrogradasi terjadi semakin cepat dan menyebabkan peningkatan kekerasan produk yang dihasilkan (Luna et al., 2015). Menurut Hasbullah dan Riskia (2013), lama perendaman beras tidak berpengaruh secara signifikan terhadap komposisi kimia yang terkandung dalam beras. Lama perendaman yang terbaik yaitu tidak lebih dari 4 jam, karena pada waktu tersebut perendaman berpengaruh tidak signifikan terhadap kadar amilosa. Oleh sebab itu, pada penelitian ini metode persiapan tepung beras merah dilakukan dengan perendaman selama 1,5 jam dan 3 jam.

Pada pembuatan kwetiau dibutuhkan pati sebagai bahan perekat yang dapat berasal dari serealia atau umbi-umbian. Pati yang dapat digunakan pada pembuatan kwetiau adalah pati yang mengandung amilopektin yang tinggi. Tapioka, tepung beras ketan, dan pati sagu merupakan tepung yang memiliki kandungan amilopektin yang tinggi. Tapioka mengandung amilopektin 
sebesar 91,94\% (Imanningsih, 2012), tepung beras ketan sebesar 99,7\% (Lukman et al., 2013), dan pati sagu sebesar $57,76 \%$ sampai $66,88 \%$ (Syafutri, 2015). Penelitian ini bertujuan untuk menganalisa karakteristik kwetiau dari tepung beras merah dengan penambahan beberapa jenis bahan perekat dan lama perendaman beras merah.

\section{BAHAN DAN METODE}

\section{Bahan}

Bahan-bahan yang digunakan dalam penelitian ini adalah: beras Merah merk "Hotel", tapioka merk"Pak Tani Gunung", tepung beras ketan merk "Rose Brend", pati sagu Bangka, garam, dan air. Alat-alat yang digunakan dalam penelitian ini adalah: alat-alat gelas, ayakan 80 mesh, baskom, blender merek "Philips", cawan aluminium, cawan porseline, chromameter merek "Conica Minolta" Jepang, dandang, desikator, hot plate, kompor, loyang almunium, nampan, neraca analitik "Ohaus" USA, pisau, plastik transparan polypropylene, sendok, Soxhlet, spektrofotometer, dan texture analyzer merek"Brookfield" USA.

\section{Metode}

\section{Rancangan Penelitian}

Penelitian ini menggunakan Rancangan Acak Lengkap Faktorial (RALF) dengan dua faktor perlakuan, yaitu (A) jenis bahan perekat dan (B) lama perendaman. Faktor A terdiri dari 3 taraf perlakuan yaitu tapioka $\left(A_{1}\right)$, tepung beras ketan $\left(A_{2}\right)$, dan sagu $\left(A_{3}\right)$. Faktor $\mathrm{B}$ terdiri dari 2 taraf perlakuan yaitu 1,5 jam $\left(B_{1}\right)$ dan 3 jam $\left(B_{2}\right)$. Penelitian ini terdiri dari 6 kombinasi perlakuan. Setiap perlakuan diulang sebanyak 3 kali.

\section{Bahan dan Alat}

Bahan yang digunakan pada penelitian ini adalah air, beras merah komersil, garam, pati sagu (dari Propinsi Bangka Belitung), tapioka, dan tepung beras ketan. Alat yang digunakan antara lain ayakan 80 mesh, baskom, blender, dandang/panci pengukus, loyang alumunium $(20 \mathrm{~cm} \times 13 \mathrm{~cm})$, oven listrik, pisau, dan sendok.

\section{Pembutan Tepung Beras Merah dan Kwetiau Tepung Beras Merah}

Penelitian ini terdiri dari dua tahap yaitu tahap pembuatan tepung beras merah dan tahap pembuatan kwetiau. Cara kerja pembuatan tepung beras merah berdasarkan metode Bharida (2018) yang telah dimodifikasi. Beras merah dibersihkan dari benda asing (gabah, batu, dan lain-lain), kemudian beras merah dicuci dengan air dan ditiriskan. Beras merah yang telah dicuci, lalu direndam dengan air selama 1,5 jam dan 3 jam dengan perbandingan beras dan air 1:2 (b/v) lalu ditiriskan. Beras merah digiling menggunakan blender kering tanpa air hingga beras hancur. Beras merah yang telah hancur dan halus disaring menggunakan ayakan 80 mesh, sehingga diperoleh tepung beras merah. Tepung beras merah diturunkan kadar airnya dengan oven pada suhu $50{ }^{\circ} \mathrm{C}$ hingga kadar air mencapai $8-12 \%$ (3 jam pengeringan untuk perendaman 1,5 jam dan 5 jam pengeringan untuk perendaman 3 jam).

Pembuatan kwetiau tepung beras merah berdasarkan Fadiati dan Ita (2009) yang telah dimodifikasi. Tepung beras merah $(50 \mathrm{~g})$, bahan perekat $(30 \mathrm{~g})$, garam $(3 \mathrm{~g})$, dan air (150 $\mathrm{mL})$ diaduk merata hingga terbentuk adonan. Adonan dituangkan dan diratakan di dalam loyang almunium persegi (ukuran $20 \mathrm{~cm} \times 13 \mathrm{~cm}$ ). Kwetiau dikukus selama 10 menit hingga permukaan kwetiau tidak lengket. Lembaran kwetiau (tebal $1 \mathrm{~mm}$, lebar $1 \mathrm{~cm}$, panjang $20 \mathrm{~cm}$ ) diiris menggunakan pisau yang tajam.

\section{Parameter Pengamatan}

Parameter yang diamati terdiri dari karakteristik fisik, kimia, dan sensoris. Karakteristik fisik meliputi warna, kekerasan, dan elongasi. Karakteristik kimia meiputi kadar air, kadar abu, dan serat kasar. Karakteristik sensoris meliputi aroma, tekstur, warna dan rasa. Parameter total antosianin hanya dilakukan pada perlakuan terbaik. Perlakuan terbaik ditentukan dari parameter kadar air dan karakteristik sensoris.

Warna kwetiau tepung beras merah 
menggunakan colour reader merek Conica Minolta. Menurut Munsell (1997), cara kerja analisa warna adalah sebagai berikut: colour reader dikalibrasi menggunakan plat standar berwarna putih. Sampel kwetiau dimasukkan ke dalam plastik transparan dan kepala optik ditempelkan pada permukaan plastik tersebut. Menu skala pembaca $L^{*}, a^{*}$, dan $b^{*}$ dipilih, kemudian tombol START ditekan hingga nilai $L^{*}, a^{*}$, dan $b^{*}$ terbaca.

Kekerasan kwetiau menggunakan alat texture analyzer merek Brookfield menurut cara kerja Farida et al. (2006). Probe dipasang tepat di atas sampel, lalu speed texture analyzer diatur. Probe menekan tepat di tengah sampel. Kemudian pada display tertera angka peak load dan final load dalam satuan gram force (gf). Angka digunakan pada penelitian ini adalah angka final load.

Pemanjangan (elongasi) kwetiau adalah perpanjangan kwetiau sampai pada titik tertentu kwetiau putus atau patah Kwetiau dipotong sepanjang $10 \mathrm{~cm}$ dan diletakkan di atas penggaris. Kemudian kwetiau ditarik secara perlahan sampai akhirnya terputus dan dicatat angka yang tertera di atas penggaris Choy et al. (2010). Persen elongasi dapat dihitung dengan rumus di bawah ini, Dimana a = panjang awal $(\mathrm{cm})$ dan $\mathrm{b}=$ panjang akhir $(\mathrm{cm})$.

Perpanjangan/Elongasi $(\%)=\frac{b-a}{a} \times 100 \%$

Kadar air kwetiau diukur menggunakan metode oven berdasarkan (AOAC, 2005). Cawan aluminium dimasukkan dalam oven selama 30 menit dan didinginkan dalam desikator selama 15 menit kemudian ditimbang berat cawannya. Sampel kwetiau $( \pm 3 \mathrm{~g})$ dimasukkan ke dalam cawan yang telah diketahui beratnya, lalu dikeringkan dengan oven pada suhu $105{ }^{\circ} \mathrm{C}$ selama 24 jam. Sampel beserta cawan dipindahkan ke dalam desikator selama 15 menit, kemudian sampel beserta cawan ditimbang. Kadar air sampel ditentukan dari berat air yang menguap. Persen kadar air dapat dihitung menggunakan rumus :

Kadar air $(\%, b b)=\frac{\text { Berat awal }(g)-\text { Berat akhir }(g)}{\text { Berat awal }(g)} \times 100 \%$

Kadar abu diukur dengan metode gravimetri (AOAC, 2005). Sampel kwetiau (5 g) yang telah dihaluskan, ditimbang dalam cawan pengabuan yang telah diketahui beratnya. Sampel dibakar sampai asapnya habis. Cawan yang berisi sampel dimasukkan ke dalam tanur dengan suhu $550{ }^{\circ} \mathrm{C}$ sampai terbentuk warna putih ke abu-abuan. Perhitungan kadar abu adalah rasio berat abu dengan berat sampel basah.

Kadar abu (\%) =

Berat sampel setelah diabukan dan krus (g)-Beratkrus kosong (g) X $100 \%$ Berat sempel awal $(g)$

Serat kasar kwetiau tepung beras merah diukur berdasarkan Amrullah (1990). Sampel dihaluskan dan ditimbang sebanyak 2 $\mathrm{g}$ bahan kering kemudian diekstraksi lemaknya dengan Soxhlet. Bahan dipindahkan ke dalam Erlenmeyer $600 \mathrm{ml}$ dan ditambahkan $0,5 \mathrm{~g}$ asbes yang telah dipijarkan dan 3 tetes anti buih. Larutan $\mathrm{H}_{2} \mathrm{SO}_{4}$ mendidih $(200 \mathrm{~mL}$ ) ditambahkan dan didinginkan dengan pendingin balik kemudian dididihkan (30 menit). Saringan disuspensi melalui kertas saring dan residu yang tertinggal dalam Erlenmeyer dicuci dengan aquadest mendidih. Residu dipindahkan dari kertas ke dalam Erlenmeyer dengan spatula dan sisanya dicuci dengan larutan $\mathrm{NaOH}$ mendidih (200 mL) sampai semua residu masuk ke dalam Erlenmeyer dan dididihkan dengan pendingin balik (30 menit). Residu disaring dengan kertas saring yang telah diketahui beratnya sambil diccuci dengan larutan $\quad \mathrm{K}_{2} \mathrm{SO}_{4} \quad 10 \%$ aquades mendidih kemudian $15 \mathrm{ml}$ alkohol 95\%. Kertas saring dan sampel dikeringkan dalam oven dengan suhu $110{ }^{\circ} \mathrm{C}$ sampai berat konstan $(1-2$ jam), didinginkan dalam desikator dan ditimbang.

Serat Kasar $(\%)=$ Berat akhir $(g)-$ Berat kertassaring $(g) \times 100 \%$ Berat sampel $(g)$

Konsentrasi antosianin kwetiau tepung beras merah diukur dengan metode $\mathrm{pH}$ differential (Prior et al. 1998). Sebanyak masing-masing 0,05 $\mathrm{ml}$ sampel dimasukkan ke dalam 2 buah tabung reaksi. Tabung reaksi pertama ditambah larutan buffer potasium klorida $(0,025 \mathrm{M}) \mathrm{pH} 1$ sebanyak 4,95 $\mathrm{mL}$, dan tabung kedua ditambahkan larutan buffer sodium asetat $(0,4 \mathrm{M}) \mathrm{pH} 4,5$ sebanyak 4,95 $\mathrm{mL}$. Pengaturan $\mathrm{pH}$ dalam pembuatan larutan buffer menggunakan $\mathrm{HCl}$ pekat. Absorbansi dari kedua $\mathrm{pH}$ diukur dengan spektrofotometer pada panjang gelombang $520 \mathrm{~nm}$ dan $700 \mathrm{~nm}$ setelah didiamkan selama 15 menit. Nilai absorbansi 
dihitung dengan rumus : $A=\left[\left(A_{520}-A_{700}\right)_{\mathrm{pH}} 1\right.$ - $\left.\left(A_{520}-A_{700}\right)_{\mathrm{pH}} 4,5\right]$. Konsentrasi antosianin dihitung sebagai sianidin-3-glikosida menggunakan koefisien ekstingsi molar sebesar $29600 \mathrm{~L} \mathrm{~cm}^{-1}$ dan berat molekul sebesar 448,8. Konsentrasi antosianin ( $\mathrm{mgL}^{-}$ $\left.{ }^{1}\right)=(A \times B M \times F P \times 1000) /(\varepsilon \times 1)$, dimana A adalah absorbansi, BM adalah berat molekul $(448,8)$, FP adalah faktor pengenceran (5 $\mathrm{mL} / 0,05 \mathrm{~mL})$, dan $\varepsilon$ adalah koefisien ekstingsi molar $\left(29600 \mathrm{Lcm}^{-1}\right)$.

Karakteristik sensoris meliputi parameter aroma, tekstur, warna, dan rasa kwetiau. Penilaian dilakukan dengan metode uji hedonik/kesukaan yang merujuk pada Pratama (2013). Pengujian dilakukan oleh 25 orang panelis semi terlatih. Sampel diletakkan di atas piring dan diberi kode tiga digit secara acak. Panelis diminta memberikan penilaian skor dalam skala berikut: 1 = sangat tidak suka; 2 = tidak suka; 3 = suka; dan $4=$ sangat suka.

\section{Analisa Data}

Data karakteristik fisik dan kimia kwetiau tepung beras merah dianalisa dengan analysis of variance atau Anova $(a=0,05)$. Perlakuan yang berpengaruh nyata dilanjutkan dengan uji Beda Nyata Jujur (BNJ $a=0,05)$. Karakteristik sensoris kwetiau tepung beras merah dianalisa dengan uji Friedman Conover.

\section{HASIL DAN PEMBAHASAN}

\section{Warna}

Pengukuran warna kwetiau tepung beras merah terdiri dari ligtness $\left(L^{*}\right)$, redness $\left(a^{*}\right)$, dan yellowness $\left(b^{*}\right)$ (Tabel 1$)$. Secara umum, hasil pengukuran uji warna kwetiau dari tepung beras merah yaitu berwarna merah. Warna kwetiau dihasilkan dari pigmen antosianin yang terkandung di dalam beras merah (Widyawati et al., 2014). Pigmen antosianin mudah larut dalam air (Effendi, 1991). Pada perlakuan 3 jam perendaman, antosianin pada beras lebih banyak larut ke dalam air dibandingkan pada perlakuan 1,5 jam perendaman. Warna kwetiau dengan perlakuan 1,5 jam perendaman lebih gelap bila dibandingkan dengan kwetiau dengan perlakuan 3 jam perendaman. Proses perendaman menyebabkan pigmen antosianin pada beras merah larut ke dalam air, semakin lama waktu perendaman maka warna produk yang dihasilkan akan semakin cerah (Pangastuti et al., 2013).

Hasil penelitian menunjukkan bahwa nilai $L^{*}$ kwetiau terendah terdapat pada perlakuan $\mathrm{A}_{2} \mathrm{~B}_{1}$ (bahan perekat tepung beras ketan; 1,5 jam perendaman), sedangkan nilai $L^{*}$ kwetiau tertinggi terdapat pada perlakuan $\mathrm{A}_{2} \mathrm{~B}_{2}$ (bahan perekat tepung beras ketan; 3 jam perendaman). Nilai $a^{*}$ terendah terdapat pada perlakuan $A_{1} B_{2}$ (bahan perekat tapioka; 3 jam perendaman), sedangkan nilai $a^{*}$ tertinggi terdapat pada perlakuan $\mathrm{A}_{1} \mathrm{~B}_{1}$ (bahan perekat tapioka; 1,5 jam perendaman). Nilai $b^{*}$ terendah terdapat pada kombinasi perlakuan $A_{3} B_{1}$ (bahan perekat sagu; 1,5 jam perendaman), sedangkan nilai $b^{*}$ tertinggi terdapat pada kombinasi perlakuan $A_{3} B_{2}$ (bahan perekat tapioka; 3 jam perendaman). Hasil penelitian menunjukkan bahwa lama perendaman beras merah (faktor B) berpengaruh nyata, sedangkan jenis bahan perekat (faktor A) dan interaksi perlakuan berpengaruh tidak nyata terhadap nilai $L^{*}$, $a^{*}$, dan $b^{*}$ kwetiau dari tepung beras merah yang dihasilkan.

Warna yang dihasilkan pada kwetiau berasal dari pigmen antosianin (Widyawati et al., 2014). Tinggi dan rendahnya kandungan pigmen akan berpengaruh terhadap warna. Semakin tinggi kandungan antosianin maka warna pada suatu produk akan semakin merah (Winata dan Yunianta, 2015). Pigmen antosianin bersifat mudah larut dalam air (Effendi, 1991). Pada perendaman 3 jam, antosianin pada beras akan lebih banyak larut ke dalam air dibandingkan pada perendaman 1,5 jam. Semakin lama perendaman, kandungan pigmen antosianin di dalam beras akan lebih banyak berkurang dan kwetiau yang dihasilkan lebih pudar yang diindikasikan dengan nilai $L^{*}$ yang lebih tinggi, penurunan nilai $a^{*}$, serta peningkatan nilai $b^{*}$. Hasil ini sejalan dengan penelitian Pangastuti et al. (2013) yang menyatakan bahwa naiknya nilai $L^{*}$ dan $b^{*}$ pada perlakuan perendaman kacang merah disebabkan oleh larutnya 
pigmen warna di dalam media perendaman.

\section{Kekerasan}

Nilai kekerasan terendah terdapat pada kwetiau dengan perlakuan $\mathrm{A}_{2} \mathrm{~B}_{2}$ (bahan perekat tepung beras ketan; 3 jam perendaman), sedangkan nilai kekerasan tertinggi terdapat pada kwetiau dengan perlakuan $A_{3} B_{1}$ (bahan perekat sagu; 1,5 jam perendaman). Hasil penelitian menunjukkan bahwa jenis bahan perekat (faktor A), lama perendaman beras merah (faktor B) dan interaksi kedua faktor berpengaruh nyata terhadap nilai kekerasan kwetiau dari tepung beras merah.

Tepung beras ketan memiliki kandungan amilopektin mencapai 99,7\% (Lukman et al., 2013), sedangkan kandungan amilopektin tapioka dan sagu adalah sebesar $83 \%$ dan 73\% (Astuti, 2009). Amilopektin merupakan fraksi dari pati yang memiliki molekul berukuran besar dengan struktur bercabang banyak dan membentuk double helix. Amilopektin yang bercabang dan membentuk double helix membuat air terperangkap di dalam granula pati dan terhalang untuk keluar, sedangkan amilosa memiliki struktur tidak bercabang yang membuat amilosa memiliki kemampuan yang rendah untuk mengikat air dan air mudah keluar (Imanningsih, 2012). Hal tersebut menyebabkan kwetiau dari tepung beras merah yang menggunakan bahan perekat yang tinggi kandungan amilopektin akan memiliki nilai kadar air yang tinggi dan memiliki tekstur yang lembut sehingga menyebabkan nilai kekerasan yang akan lebih rendah.

Beras merah memiliki kandungan amilosa yang cukup tinggi yaitu $40 \%$ dan kandungan amilopektin yang rendah yaitu $60 \%$ (Sompong et al., 2011). Amilosa merupakan polimer yang memiliki rantai lurus, tetapi beberapa molekul amilosa memiliki cabang yang berbentuk terlalu panjang atau terlalu pendek, dipisahkan oleh jarak yang jauh dan tidak membentuk double helix. Hal ini menyebabkan molekul-molekul dapat bersifat seperti rantai lurus dan dapat mudah mengalami retrogradasi (Bemiller, 2007). Bentuk rantai polimer yang lurus menjadikan amilosa cenderung mudah melepaskan air dan menyebabkan produk akan pera atau gel yang keras. Pada saat proses perendaman, struktur biji beras akan melonggar dan melunak yang disebabkan oleh hidrasi, hal ini akan menghasilkan tepung dengan kerusakan pati lebih sedikit (Chiang dan Yeh, 2002). Rendahnya kerusakan pati pada tepung menyebabkan meningkatnya daerah kristalin amilosa yang tersisa dalam granula pati sehingga menurunkan kemampuan gelatinisasi (Morrison dan Tester, 1994). Semakin tinggi struktur kristalin pada granula maka semakin lama granula pati akan mengalami proses gelatinisasi (Chen et al., 1999; Suksomboon dan Naivikul, 2006). Granula yang mengalami proses gelatinisasi lebih lama akan lebih lama pula mengalami proses retrogradasi ketika suhu turun (Indriyani et al., 2013). Menurut Sandhu et al. (2010), proses retrogradasi akan meningkatkan kekerasan produk yang dihasilkan. Oleh karena itu kwetiau yang dihasilkan dari perlakuan 3 jam perendaman memiliki nilai kekerasan yang lebih rendah atau lebih lunak karena dengan waktu perendaman yang semakin lama maka kerusakan pati yang terjadi akan semakin rendah dan proses retrogradasi semakin lama.

Kwetiau dari tepung beras merah perlakuan $\mathrm{A}_{2} \mathrm{~B}_{2}$ (bahan perekat tepung beras ketan; 3 jam perendaman) memiliki nilai kekerasan yang paling rendah, hal ini disebabkan oleh tingginya kandungan amilopektin dari tepung beras ketan yaitu sebesar 99,7\% (Lukman et al., 2013) dan lama perendaman yang menyebabkan rendahnya kerusakan pati pada tepung beras merah (Chiang dan Yeh, 2002). Tingginya kandungan amilopektin dan rendahnya tingkat kerusakan pati menyebabkan proses retrogradasi yang terjadi pada kwetiau dari tepung beras merah perlakuan $\mathrm{A}_{2} \mathrm{~B}_{2}$ akan lebih lambat dari pada kwetiau perlakuan lainnya, sehingga nilai kekerasannya paling rendah. 
Tabel 1. Karakteristik Fisik Kwetiau Tepung Beras Merah

\begin{tabular}{|c|c|c|c|c|c|c|}
\hline \multirow[b]{2}{*}{$\begin{array}{l}\text { Karakteristik } \\
\text { Fisik Kwetiau }\end{array}$} & \multicolumn{2}{|c|}{ Bahan Perekat Tapioka } & \multicolumn{2}{|c|}{$\begin{array}{c}\text { Bahan Perekat Tepung } \\
\text { Beras Ketan }\end{array}$} & \multicolumn{2}{|c|}{ Bahan Perekat Sagu } \\
\hline & $\begin{array}{c}\text { Perendaman } \\
\text { 1,5 Jam }\end{array}$ & $\begin{array}{c}\text { Perendaman } \\
3 \mathrm{Jam}\end{array}$ & $\begin{array}{c}\text { Perendaman } \\
1,5 \mathrm{Jam}\end{array}$ & $\begin{array}{c}\text { Perendama } \\
\text { n } \\
3 \mathrm{Jam}\end{array}$ & $\begin{array}{c}\text { Perendaman } \\
\text { 1,5 Jam }\end{array}$ & $\begin{array}{c}\text { Perendaman } \\
3 \text { Jam }\end{array}$ \\
\hline Lightness (\%) & 48,70 & 51,67 & 48,17 & 51,87 & 48,23 & 51,03 \\
\hline Redness & 15,50 & 12,27 & 15,43 & 12,37 & 15,27 & 12,50 \\
\hline Yellowness & 9,77 & 10,47 & 9,67 & 10,40 & 9,53 & 10,70 \\
\hline Kekerasan (gf) ${ }^{*}$ & $81,75^{d}$ & $73,73^{c}$ & $61,28^{b}$ & $52,02^{\mathrm{a}}$ & $163,67^{f}$ & 145,99 \\
\hline Elongasi (\%) & 20,33 & 20,67 & 24,67 & 25,67 & 5,00 & 5,00 \\
\hline
\end{tabular}

\section{Elongasi}

Nilai elongasi terendah terdapat pada perlakuan $A_{3} B_{1}$ (bahan perekat sagu; 1,5 jam perendaman), sedangkan nilai elongasi tertinggi terdapat pada perlakuan $A_{2} B_{2}$ (bahan perekat tepung beras ketan; 3 jam perendaman). Hasil analisa keragaman menunjukkan bahwa jenis bahan perekat (faktor $A$ ) berpengaruh nyata terhadap nilai elongasi kwetiau dari tepung beras merah yang dihasilkan, sedangkan lama perendaman (faktor B) dan interaksi kedua faktor perlakuan berpengaruh tidak nyata.

Elongasi adalah perubahan panjang mie maksimum saat memperoleh gaya tarik sampai mie putus. Elongasi dipengaruhi oleh proporsi amilosa dan amilopektin maupun proses adonan (Fitriani, 2016). Pati sagu memiliki kandungan amilopektin paling rendah yaitu sebesar $73 \%$, sedangkan kandungan amilopektin tapioka adalah sebesar 83\% (Astuti, 2009) dan kandungan amilopektin tepung beras ketan adalah sebesar 99,7\% (Lukman et al., 2013). Semakin tinggi kandungan amilopektin yang terdapat pada bahan perekat maka semakin elastis kekerasan kwetiau sehingga nilai elongasinya semakin besar. Nilai elongasi berbanding terbalik dengan nilai kekerasan. Semakin tinggi nilai kekerasan, maka kwetiau yang dihasilkan akan memiliki sifat kaku maka nilai keelastisitasannya semakin rendah atau mudah putus. Hal ini sejalan dengan penelitian yang dikemukakan oleh Indrianti et al. (2014) yang menyatakan bahwa mie jagung yang memiliki nilai elongasi yang tinggi memiliki nilai kadar air yang tinggi juga, tetapi memiliki nilai kekerasan yang rendah.

\section{Kadar Air}

Hasil penelitian menunjukkan bahwa nilai kadar air kwetiau dari tepung beras merah terendah terdapat pada perlakuan $A_{3} B_{1}$ (bahan perekat sagu; 1,5 jam perendaman), sedangkan nilai kadar air tertinggi terdapat pada perlakuan $A_{2} B_{2}$ (bahan perekat tepung beras ketan; 3 jam perendaman) (Gambar 1). Menurut BSN (2015), kadar air mie basah matang adalah maksimal 65\%. Hasil penelitian menunjukkan bahwa jenis bahan perekat (faktor A), lama perendaman beras merah (faktor B) dan interaksi keduanya berpengaruh nyata terhadap nilai kadar air kwetiau dari tepung beras merah yang dihasilkan.

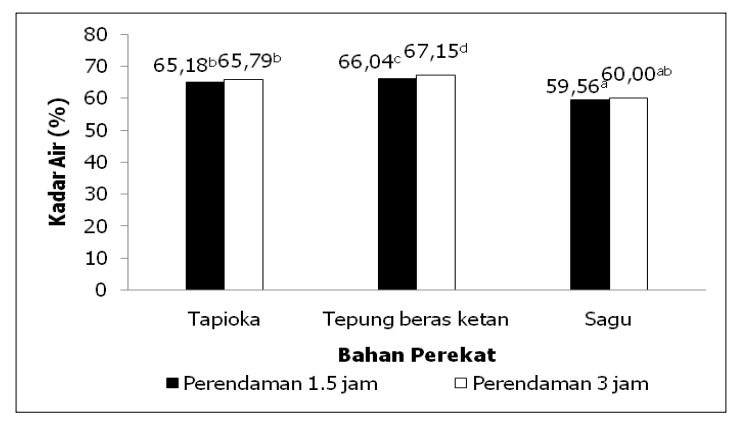

Gambar 1. Kadar Air (\%) Rata-rata Kwetiau Tepung Beras Merah

Tepung beras ketan memiliki kandungan amilopektin yang paling tinggi jika dibandingkan bahan perekat lain yang digunakan. Amilopektin merupakan fraksi dari pati yang memiliki molekul berukuran besar dengan struktur bercabang banyak dan membentuk double helix. Double helix membuat air terperangkap di dalam granula pati dan terhalang untuk keluar. Pada saat penambahan air dan terjadi proses pemasakan, double helix dari amilopektin 
akan merenggang dan terlepas saat ada ikatan hidrogen yang terputus. Ketika ikatan hidrogen terputus, amilopektin akan membuat air terperangkap di dalam granula pati (Imanningsih, 2012). Oleh karena itu, semakin tinggi kandungan amilopektin yang terkandung di dalam bahan perekat akan membuat kadar air kwetiau semakin tinggi juga.

Nilai kadar air kwetiau dari tepung beras merah dengan perlakuan perendaman yang lebih lama adalah lebih tinggi. Hal ini dikarenakan kerusakan pati beras akibat proses perendaman yang lebih rendah. Chiang dan Yeh (2002) menyatakan bahwa proses perendaman menyebabkan struktur biji beras akan melonggar dan melunak yang disebabkan oleh hidrasi. Hal ini akan menghasilkan tepung dengan kerusakan pati lebih sedikit. Rendahnya kerusakan pati pada tepung menyebabkan meningkatnya daerah kristalin amilosa yang tersisa dalam granula pati sehingga menurunkan kemampuan mengikat air (Morrison dan Tester, 1994). Semakin tinggi struktur kristalin pada granula maka semakin lama granula pati akan mengalami proses pengikatan air (Chen et al., 1999; Suksomboon dan Naivikul, 2006), sehingga rendahnya proses retrogradasi yang menyebabkan kadar air lebih tinggi. Menurut Indriyani et al. (2013), granula yang memiliki kemampuan mengikat air lebih cepat akan lebih cepat pula mengalami proses retrogradasi ketika suhu turun.

Nilai kadar air berbanding terbalik dengan nilai kekerasan (Tabel 1), kadar air yang tinggi akan menghasilkan kwetiau yang lebih lembut dan nilai kekerasannya rendah, tetapi berbanding lurus dengan sifat elastisitasnya. Kwetiau yang memiliki nilai kadar air yang tinggi akan memiliki nilai elongasi yang tinggi juga atau kwetiau akan semakin elastis.

\section{Kadar Abu}

Kadar abu kwetiau dari tepung beras merah terendah terdapat pada perlakuan $A_{1} B_{2}$ (bahan perekat tapioka; 3 jam perendaman), sedangkan nilai kadar abu tertinggi terdapat pada perlakuan $A_{2} B_{1}$ (bahan perekat tepung beras ketan; 3 jam perendaman) (Gambar 2). Hasil penelitian menunjukkan bahwa lama perendaman (faktor $B$ ) berpengaruh nyata, sedangkan jenis bahan perekat (faktor $A$ ) dan interaksi kedua faktor berpengaruh tidak nyata terhadap nilai kadar abu kwetiau dari tepung beras merah yang dihasilkan.

Nilai kadar abu dari beras merah sebesar 1,18\% (Fibriyanti, 2012). Menurut Litaay dan Santoso (2013), proses perendaman dapat menurunkan kadar abu pada bahan pangan karena unsur-unsur mineral yang terdapat pada bahan dapat leaching saat perendaman. Hal ini sejalan dengan hasil penelitian bahwa kwetiau yang diperoleh dari tepung beras merah dengan perlakuan 3 jam perendaman memiliki nilai kadar abu lebih rendah dibandingkan dengan 1,5 jam perendaman.

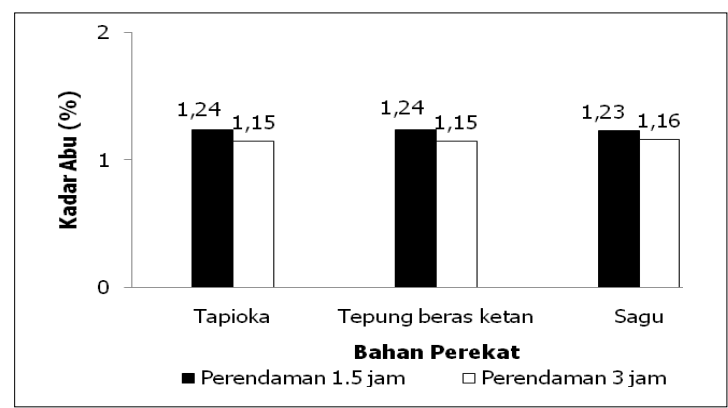

Gambar 2. Kadar Abu (\%) Rata-rata Kwetiau Tepung Beras Merah

\section{Serat Kasar}

Serat kasar merupakan residu dari bahan makanan atau hasil pertanian setelah diperlakukan dengan asam atau alkali mendidih, dan terdiri dari selulosa, dengan sedikit lignin dan pentosa. Serat sangat penting untuk proses memudahkan dalam pencernaan di dalam tubuh agar proses pencernaan tersebut lancer (peristaltik) (Hermayanti et al., 2006). Berdasarkan hasil penelitian ini, kadar serat dalam kwetiau dari tepung beras merah berkisar antara 2,40\% hingga 2,42\% (Gambar 3). Perlakuan $A_{1} B_{2}$ (bahan perekat tapioka; 3 jam perendaman) memiliki kadar serat kasar tertinggi dan perlakuan $\mathrm{A}_{2} \mathrm{~B}_{2}$ (bahan perekat tepung beras ketan; 3 jam perendaman) memiliki nilai 
kadar serat kasar terendah.

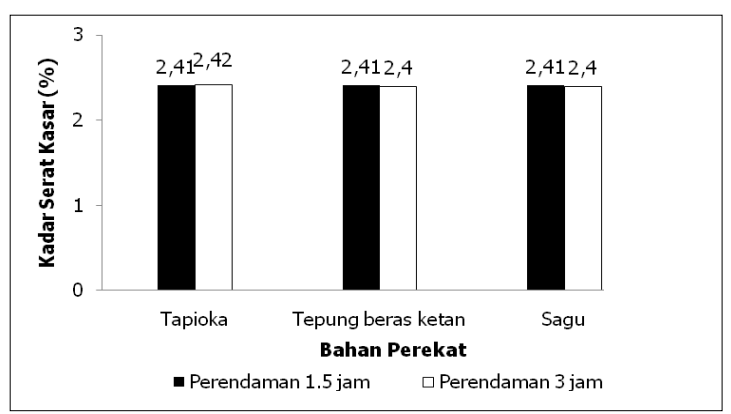

Gambar 3. Kadar Serat Kasar (\%) Rata-rata Kwetiau Tepung Beras Merah

Hasil penelitian menunjukkan bahwa faktor A (jenis bahan perekat), faktor B (lama perendaman), dan interaksi keduanya berpengaruh tidak nyata terhadap nilai serat kasar kwetiau dari tepung beras merah. Serat kasar yang terdapat pada kwetiau dari tepung beras merah berasal dari beras merah. Menurut Hernawan dan Melyani (2016), kandungan serat kasar pada beras merah sebesar 3,97\%.

\section{Karakteristik Sensoris}

Karakteristik sensoris kwetiau tepung beras merah meliputi aroma, warna, tekstur dan rasa (Tabel 2). Aroma merupakan salah satu faktor penting dalam penilaian produk pangan. Menurut Setyaningsih et al. (2010), aroma berkaitan dengan indera penciuman, seseorang dapat mendeteksinya karena adanya senyawa volatil yang dilepas oleh suatu produk. Skor hedonik aroma kwetiau tepung beras merah berkisar antara 2,76 hingga 3,04 (suka). Skor hedonik aroma terendah terdapat pada perlakuan $\mathrm{A}_{2} \mathrm{~B}_{1}$ (bahan perekat tepung beras ketan; 1,5 jam perendaman), $A_{3} B_{1}$ (bahan perekat sagu; 1,5 jam perendaman), dan $A_{3} B_{2}$ (bahan perekat sagu; 3 jam perendaman), sedangkan skor hedonik aroma tertinggi terdapat pada perlakuan $\mathrm{A}_{1} \mathrm{~B}_{2}$ (bahan perekat tapioka; 3 jam perendaman). Hasil uji lanjut Friedman Conover menunjukkan bahwa interaksi antara faktor A (jenis bahan perekat) dan faktor B (lama waktu perendaman) berpengaruh tidak nyata terhadap aroma kwetiau tepung beras merah.

Warna sangat penting dalam suatu bahan pangan. Menurut Winarno (2002), warna merupakan komponen penting untuk menentukan kualitas atau derajat penerimaan suatu bahan pangan. Penentuan mutu suatu bahan pangan pada umumnya tergantung pada warna, karena warna merupakan parameter yang pertama kali terlihat oleh indra (Sudjono, 1985). Skor hedonik warna kwetiau tepung beras merah berkisar antara 2,44 (tidak suka) hingga 3,36 (suka). Skor hedonik warna terendah terdapat pada perlakuan $\mathrm{A}_{2} \mathrm{~B}_{2}$ (bahan perekat tepung beras ketan; 3 jam perendaman) dan skor hedonik warna tertinggi terdapat pada perlakuan $A_{1} B_{2}$ (bahan perekat tapioka; 3 jam perendaman).

Berdasarkan uji lanjut Friedman Conover, skor hedonik warna kwetiau dari tepung beras merah perlakuan $A_{2} B_{2}$ (bahan perekat tepung beras ketan; 3 jam perendaman) dan perlakuan $\mathrm{A}_{2} \mathrm{~B}_{1}$ (bahan perekat tepung beras ketan; 1,5 jam perendaman) berbeda tidak nyata, tetapi berbeda nyata dengan perlakuan lainnya. Panelis memberikan penilaian tingkat kesukaan tertinggi pada perlakuan $A_{1} B_{2}$ (bahan perekat tapioka; 3 jam perendaman) dan perlakuan $\mathrm{A}_{3} \mathrm{~B}_{1}$ (bahan perekat sagu; 1,5 jam perendaman). Masing- masing memiliki nilai analisa warna $L^{*}, a^{*}$ dan $b^{*}$ sebesar $51,67 \%, 12,27$ dan 10,47 untuk perlakuan $A_{1} B_{2}$ dan 48,23\%, 15,27 dan 9,53 untuk perlakuan $A_{3} B_{1}$. Tepung beras ketan memberikan warna yang keruh terhadap kwetiau, karena tepung beras ketan memiliki kemampuan swelling power yang tinggi dibandingkan tapioka dan sagu. Pati yang memiliki kemampuan swelling power yang tinggi memiliki gel yang lebih keruh (Balagopalan et al., 1988). Sehingga kwetiau dari tepung beras merah yang menggunakan tepung beras ketan sebagai bahan perekat memiliki skor hedonik yang cenderung tidak disukai panelis. 
Tabel 2. Karakteristik Sensoris Kwetiau Tepung Beras Merah

\begin{tabular}{|c|c|c|c|c|c|c|}
\hline \multirow{2}{*}{$\begin{array}{c}\text { Parameter } \\
\text { Sensoris }\end{array}$} & \multicolumn{2}{|c|}{ Bahan Perekat Tapioka } & \multicolumn{2}{|c|}{$\begin{array}{c}\text { Bahan Perekat Tepung } \\
\text { Beras Ketan }\end{array}$} & \multicolumn{2}{|c|}{ Bahan Perekat Sagu } \\
\hline & $\begin{array}{c}\text { Perendaman } \\
1,5 \mathrm{Jam}\end{array}$ & $\begin{array}{l}\text { Perendaman } \\
3 \text { Jam }\end{array}$ & $\begin{array}{c}\text { Perendaman } \\
1,5 \mathrm{Jam}\end{array}$ & $\begin{array}{c}\text { Perendaman } \\
3 \mathrm{Jam}\end{array}$ & $\begin{array}{c}\text { Perendaman } \\
1,5 \text { Jam }\end{array}$ & $\begin{array}{c}\text { Perendaman } \\
3 \mathrm{Jam}\end{array}$ \\
\hline Aroma & 2,84 & 3,04 & 2,76 & 2,84 & 2,76 & 2,76 \\
\hline Warna* & $3,16^{\mathrm{bc}}$ & $3,36^{c}$ & $2,48^{a}$ & $2,44^{a}$ & $3,32^{c}$ & $2,92^{b}$ \\
\hline Tekstur* & $3,08^{b}$ & $3,12^{\mathrm{b}}$ & $2,32^{\mathrm{a}}$ & $2,20^{\mathrm{a}}$ & $2,24^{a}$ & $2,20^{a}$ \\
\hline Rasa & 2,64 & 2,64 & 2,32 & 2,80 & 2,60 & 2,68 \\
\hline
\end{tabular}

${ }^{*}$ Angka-angka yang diikuti huruf yang sama pada baris yang sama menunjukkan perlakuan berbeda tidak nyata

Tekstur merupakan sesuatu yang berhubungan dengan mekanik, rasa, sentuhan, penglihatan dan pendengaran yang meliputi penilaian terhadap kebasahan, kering, keras, halus, kasar dan berminyak. Penilaian tekstur makanan dapat dilakukan menggunakan jari, gigi dan langit-langit. Faktor tekstur diantaranya adalah rabaan oleh tangan, keempukan dan mudah dikunyah (Setyaningsih et al, 2010). Skor hedonik tekstur kwetiau tepung beras merah berkisar antara 2,20 (tidak suka) hingga 3,08 (suka). Skor hedonik tekstur terendah terdapat pada perlakuan $A_{2} B_{2}$ (bahan perekat tepung beras ketan; 3 jam perendaman) dan $A_{3} B_{2}$ (bahan perekat sagu; 3 jam perendaman), sedangkan skor hedonik tekstur tertinggi terdapat pada perlakuan $\mathrm{A}_{1} \mathrm{~B}_{2}$ (bahan perekat tapioka; 3 jam perendaman).

Berdasarkan uji lanjut Friedman Conover, skor hedonik tekstur kwetiau perlakuan $A_{1} B_{1}$ (bahan perekat tapioka; 1,5 jam perendaman) dan perlakuan $A_{1} B_{2}$ (bahan perekat tapioka; 3 jam perendaman) berbeda tidak nyata, tetapi berbeda nyata dengan perlakuan lainnya. Hasil uji hedonik menunjukkan bahwa kwetiau dengan tapioka sebagai bahan perekat $\left(A_{1}\right)$ lebih disukai dibandingkan kwetiau yang menggunakan bahan perekat lain. Hal ini disebabkan oleh tekstur yang dihasilkan agak elastis dan tidak terlalu lengket dengan rata-rata nilai tekstur berkisar $73,73 \mathrm{gf}$ hingga 81,75 gf dan ratarata nilai elongasi berkisar 20,33\% hingga $20,67 \%$. Skor hedonik tekstur kwetiau dari tepung beras merah dengan penambahan tepung beras ketan dan sagu lebih rendah dibandingkan kwetiau dari tepung beras merah dengan penambahan tapioka. Kwetiau dari tepung beras merah dengan penambahan tepung beras ketan memiliki nilai tekstur yang paling rendah yang berarti kwetiau yang dihasikan terlalu lembut, sedangkan kwetiau dari tepung beras merah dengan penambahan sagu memiliki nilai tekstur yang paling tinggi yang berarti kwetiau yang dihasikan terlalu keras.

Rasa merupakan tanggapan atas adanya rangsangan kimiawi di indera pengecap lidah, khususnya jenis rasa dasar yaitu manis, asin, asam dan pahit (Meilgaard et al., 2000). Skor hedonik rasa kwetiau tepung beras merah berkisar antara 2,32 (tidak suka) hingga 2,80 (suka). Skor hedonik rasa terendah terdapat pada perlakuan $A_{2} B_{1}$ (bahan perekat sagu; 1,5 jam perendaman) dan skor hedonik rasa tertinggi terdapat pada perlakuan $\mathrm{A}_{2} \mathrm{~B}_{2}$ (bahan perekat tepung beras ketan; 3 jam perendaman). Hasil uji lanjut Friedman Conover menunjukkan bahwa interaksi antara faktor $\mathrm{A}$ (jenis bahan perekat) dan faktor B (lama perendaman) berpengaruh tidak nyata terhadap rasa kwetiau dari tepung beras merah.

\section{Total Antosianin}

Antosianin merupakan zat turunan dari flavonoid, yang merupakan zat pigmen yang memberikan warna kemerah-merahan hingga ungu yang secara alami terdapat pada tumbuhan, antosianin ini memiliki sifat larut air (Suardi, 2005). Analisa total antosianin dilakukan hanya pada perlakuan terbaik yaitu $A_{1} B_{1}$ (bahan perekat tapioka; 1,5 jam perendaman). Perlakuan terbaik diperoleh berdasarkan hasil uji hedonik (aroma, rasa, kekerasan, dan warna) serta parameter kadar air (SNI 2987-2015). 
Berdasarkan hasil penelitian, perlakuan $A_{1} B_{1}$ (bahan perekat tapioka; 1,5 jam perendaman) memiliki nilai antosianin sebesar $12,51 \mathrm{mg} \cdot \mathrm{L}^{-1}$. Antosianin yang terdapat pada produk kwetiau dari tepung beras merah tergolong rendah. Menurut Muliarta et al. (2009), suatu senyawa dikatakan sebagai antosianin tinggi apabila nilai antosianin $(\mathrm{mg} / 100 \mathrm{~g})<20=$ rendah, $(\mathrm{mg} / 100 \mathrm{~g}) 20-40$ $=$ sedang, dan $(\mathrm{mg} / 100 \mathrm{~g})>40=$ tinggi. Rendahnya nilai total antosianin yang terdapat pada kwetiau ini disebabkan oleh adanya proses perendaman dan juga proses pemanasan, dimana pada saat perendaman zat warna akan larut di dalam media perendaman. Kumalaningsih (2006) menyatakan bahwa antosianin merupakan pigmen warna yang bersifat larut di dalam air dan dapat mengalami kerusakan pada proses pengolahan dengan suhu yang tinggi.

\section{KESIMPULAN}

Jenis bahan perekat berpengaruh nyata terhadap tekstur, elongasi dan kadar air, sedangkan lama perendaman berpengaruh nyata terhadap warna $\left(L^{*}, a^{*}, b^{*}\right)$, tekstur, kadar air dan kadar abu. Interaksi antara jenis bahan perekat dan lama perendaman berpengaruh nyata terhadap tekstur dan kadar air. Perlakuan terbaik yaitu kwetiau dengan bahan perekat tapioka dan lama perendaman beras 1,5 jam $\left(A_{1} B_{1}\right)$ yang diperoleh berdasarkan hasil uji hedonik (aroma, rasa, kekerasan, dan warna) serta parameter kadar air (SNI 2987-2015). Kwetiau dengan perlakuan $\mathrm{A}_{1} \mathrm{~B}_{1}$ memiliki nilai L* 48,70\%, $\quad a^{*} 15,50, b^{*} 9,77$, kekerasan $81,75 \mathrm{gf}$, elongasi $20,33 \%$, kadar air $65,18 \%$, kadar abu 1,24\%, kadar serat kasar 2,41\%, serta skor hedonik aroma 2,84, warna 3,16, tekstur 3,08, dan rasa 2,64 (termasuk kategori suka). Kwetiau perlakuan $A_{1} B_{1}$ memiliki nilai antosianin sebesar 12,51 $\mathrm{mg} \cdot \mathrm{L}^{-1}$.

\section{DAFTAR PUSTAKA}

AOAC. 2005. Official Methods of Analysis. Association of Official Analytycal
Chemistry. Washington DC. United State of America.

Askanovi, D. 2011. Kajian Resistensi Beras Pecah Kulit dan Beras Sosoh dari Lima Varietas Padi Unggul Terhadap Serangan Hama Beras Sitophilus oryzae (L.). Skripsi (dipublikasikan). Fakultas Teknologi Pertanian. Institut Pertanian Bogor. Bogor.

Astawan, M. 2012. Beras Merah Tangkal Kanker dan Diabetes. http://library.monx007.com/health/beras merah_tangkal_kanker_dan_diabetes/ 1. Diakses pada tanggal 20 juni 2018.

Astuti, E. F. 2009. Pengaruh Jenis Tepung dan Cara Pemasakan Terhadap Mutu Bakso dari Surimi Ikan Hasil Tangkap Sampingan (HTS). Skripsi (dipublikasikan). Fakultas Perikanan dan Ilmu Kelautan. Institut Pertanian Bogor. Bogor.

BSN (Badan Standarisasi Nasional). 2015. Standar Mutu Mie Basah (SNI 29872015). Badan Standardisasi Nasional. Jakarta.

Bemiller, J.N. 2007. Starches, Modified Food Starches, and Other Products from Starches Carbohydrate Chemistry for Food Scientists. Aacc.173-224.

Bharida, D. 2018. Sifat Fisik, Kimia, dan Sensoris Burgo dari Beras Merah (Oryza sativa var. Metik Wangi). Skripsi. Fakultas Pertanian. Universitas Sriwijaya. Palembang.

Chen, J.J., Lu, S., and Lii, C. Y. 1999. Effects of Milling on The Physicochemical Characteristics Ofwaxy Rice in Taiwan. Cereal Chem 76: 796-799.

Chiang, P. Y. and Yeh, A.I. 2002. Effect of Soaking on Wet-Milling of Rice. $J$ Cereal Sci. 35: 85-94.

Choy, Ai-ling., J.G. Hughes, and D.M. Small. 2010. The Effect of Microbial Transglutaminase, Sodium Steroyl Lactylate and Water on the Quality of Instant Fried Noodles. Journal of Food Chemistry 122: 957-964.

Effendi, W. 1991. Ekstraksi, Purifikasi dan Karakterisasi Antosianin dari Kulit Manggis (Garcinia mangostana L.). Skripsi (dipublikasikan). Fakultas 
Versi Online:

http://www.profood.unram.ac.id/index.php/profood e-ISSN: 2443-3446

Teknologi Pertanian. Institut Pertanian Bogor. Bogor.

Fadiati, A., Mahdiyah, dan Ita, W. 2009. Pengaruh Perbedaan Persentase Tepung Komposit terhadap Kualitas Hasil Pemasakan Kwetiau Instan. Seminar Nasional. PKK. Universitas Negeri Jakarta. Jakarta.

Farida, D.N., Kusmaningrum, H.D., Wulandari, N., dan Indrasti, D. 2006. Analisa Laboratorium Departemen IImu dan Teknologi Pangan. Institut Pertanian Bogor. Bogor.

Fibriyanti, Y.W. 2012. Kajian Kualitas Kimia dan Biologi Beras Merah (Oryza nivara) dalam Beberapa Pewedahan Selama Penyimpanan. Skripsi (dipublikasikan). Fakultas Pertanian. Universitas Sebelas Maret. Surakarta.

Fitriani, R.J, Ratuf, R., dan Purwani, E. 2016. Substitusi Tepung Sorgum Terhadap Elongasi dan Daya Terima Mie Basah dengan Volume Air yang Proporsional. Program Studi Ilmu Gizi Fakultas Ilmu Kesehatan. Universitas Muhammadiyah. Surakarta.

Fu, B.X., 2008. Asian noodles: History, Classification, Raw Materials, and Processing. Journal of Food Research International 41(9): 888-902.

Hasbullah, R., dan Riskia, P. 2013. Pengaruh Lama Perendaman Terhadap Mutu Beras Pratanak Pada Padi Varietas IR 64. Jurnal Ketektikan Pertanian 27(1): 53-60.

Hermayanti, Yeni, dan Eli, G. 2006. Modul Analisa Proksimat. Padang: SMAK 3 Padang. Sumatera Barat.

Hernawan, E., dan Melyani, V., 2016. Analisis Karakteristik Fisikokimia Beras Putih, Beras Merah, dan Beras Hitam (Oryza sativa L., Oryza nivara dan Oryza sativa L. Indica). Jurnal Kesehatan Bakti Tunas Husada 15(1): 79.

Hormdok, R., dan Noomhorm, A. 2007. Hydrothermal Treatment of Rice Starch for Improvement of Rice Noodle Quality. Journal of Food Science and Tecnology 40: 1723-1731.

Imanningsih, N. 2012. Profil Gelatinisasi Beberapa Formulasi Tepung-Tepungan
Pro Food (Jurnal Ilmu dan Teknologi Pangan)

Vol 6 No. 1 Mei 2020

ISSN: 2443-1095

Untuk Pendugaan Sifat Pemasakan. Penel Gizi Makan 35(1): 13-22.

Indrianti, N., Sholichah, E., dan Darmajana, D.A. 2014. Proses Pembuatan Mi Jagung Dengan Bahan Baku Tepung Jagung 60 Mesh dan Teknik SheetingSlitting. Pangan 23(3): 256-267.

Indriyani, F., Nurhidajah., dan Suyanto, A. 2013. Karakteristik Fisik, Kimia dan Sifat Organoleptik Tepung Beras Merah Berdasarkan Variasi Lama Pengeringan. Jurnal Pangan dan Gizi 4(8): 27-34.

Kumalaningsih, S. 2006. Antioksidan Alami Penangkal Radikal Bebas. Trubus Agrisarana. Surabaya.

Litaay, C., dan Santoso, J. 2013. Pengaruh Perbedaan Metode Perendaman dan Lama Perendaman Terhadap Karakteristik Fisiko-Kimia Tepung Ikan Cakalang (Katsuwonus pelamis). Jurnal IImu dan Teknologi Kelautan Tropis 5(1): 85-92.

Lukman, A., Anggraini, D., Rahmawati, N., dan Suhaeni, N. 2013. Pembuatan dan Uji Sifat Fisikokimia Pati Beras Ketan Kampar yang Dipragelatinasi. Jurnal Penelitian Farmasi Indonesia 1(2): 6771.

Luna, P., Herawati, H., Widowati, S., dan Prianto, A.B. $2015 . \quad$ Pengaruh Kandungan Amilosa Terhadap Karakteristik Fisik dan Organoleptik Nasi Instan. Jurnal Penelitian Pascapanen Pertanian 12(1): 1-10.

Meilgaard, M., Civile, G. V., Carr, B. T. 2000. Sensory Evaluation Techniques. CRC Press. Boca Raton, Florida.

Morrison, W.R., and Tester, R.F. 1994. Properties of Damaged Starch Granules. IV. Composition of Ball-Milled Wheat Starches And of Fractions Obtained on Hydration. J. Cereal Sci. 20: 69-77.

Muliarta, A.I.G.P. 2009. Korelasi Fenotipik, Genotipik dan Sidik Lintas Serta Implikasinya Pada Seleksi Padi Beras Merah. J Crop Agro. 2(1).

Mutters, R.G., and Thompson, J. F. 2009. Rice Quality Handbook. California: The Regents of the Universitas of California Agriculture and Natural Resources. 
Versi Online:

http://www.profood.unram.ac.id/index.php/profood e-ISSN: 2443-3446

Nugraha, D. H. 1996. Pengaruh Berbagai Tingkat Penyosohan Beras terhadap Kadar Antinutrisi dalam Fraksi Sosohnya. Skripsi (dipublikasikan). Fakultas Teknologi Pertanian. Institut Pertanian Bogor. Bogor.

Pangastuti, H. A., Affandi, D. R., dan Ishartani, D. 2013. Karakterisasi Sifat Fisik dan Kimia Tepung Kacang Merah (Phaseolus vulgaris L.) dengan Beberapa Perlakuan Pendahuluan. Jurnal Teknosains Pangan, 2(1): 20-29.

Pratama, F. 2014. Evaluasi Sensoris. Unsri Press. Palembang.

Prior, R.L., Cao, G., Martin, A., Sofic, E., McEwen, J., O'Brien, C., Lischner, N.,Ehlenfeldt, M., Kalt, W., Krewer, G., and Mainland, C.M. 1998. Antioxidant Capacity as Influenced by Total Phenolic and Anthocyanin Content, Maturity and Variety of Vaccinium Species. J. Agric. Food Chem 46(7): 2686-2693.

Santika, A., dan Rozakurniati. 2010. Teknik Evaluasi Mutu Beras dan Beras Merah Pada Beberapa Galur Padi Gogo. Buletin Teknik Pertanian, 15(1): 1-5.

Setyaningsih, D., Apriyantono, A., Sari, M.P. 2010. Analisa Sensoris untuk Industri Pangan dan Agro. IPB Press. Bogor.

Sandhu KS, Singh N, and Malhi NS. 2010. Physicochemical and Thermal Properties of Starches Separated From Corn Produced From Crosses of Two Germ Pools. J Food Chem., 89: 541548.

Sompong, R., Sienbenhandlehn, S., Martin, G. L., and Berhofer, E. 2011. Physicochemical and Antioxidantive Properties of Redand Black Rice Varieties from Thailand, China and Sri Lanka. J Food Chem., 124:132-140.

Suardi, D. 2005. Potensi Beras Merah Untuk Peningkatan Mutu Pangan. Jurnal Penelitian dan Pengembangan Pertanian, 24 (3).

Sudjono. M. 1985. Uji Citarasa dan Penerapan Uji Statistika dalam Peneltian. Pustaka Setia. Bandung.

Suksomboom, A. and Naivikul, O. 2006. Effect of Dry-And Wet-Milling Processes on
Pro Food (Jurnal Ilmu dan Teknologi Pangan)

Vol 6 No. 1 Mei 2020

ISSN: 2443-1095

Chemical, Physicochemical Properties and Starch Molecular Structures of Rice Starches. Kasetsart J. (Nat Sci) 40 (Suppl): 125- 134.

Supriyadi, D. 2012. Study on Effects of Amylose Amylopectin Ratio and Water Content to Crispiness and Hardness of Fried Product Model. Department of Food Science and Technology. Faculty of Agricultural Engineering and Technology. Institut Pertanian Bogor. Bogor.

Syafutri, M.I. 2015. Sifat Fungsional dan Sifat Pasta Pati Sagu Bangka. SAGU, 14(1): 1-5.

Thoif, R.A. 2014. Formulasi Substitusi Tepung Beras Merah (Oryza nivara) dan Ketan Hitam (Oryza sativa glutinosa) dalam Pembuatan Cookies Fungsional. Skripsi (dipublikasikan). Fakultas Ekologi Manusia. Institut Pertanian Bogor. Bogor.

Tanzil, V.J. 2012. Karakteristik Kwetiau yang Disubtitusi dengan Beras Merah. Skripsi (dipublikasikan). Jurusan Teknologi Pangan. Universitas Pelita Harapan. Tanggerang

United State Departement of Agriculture [USDA]. 2010. rice. USDA National Nutrient Database for Standard Reference. http://www.nal.usda.gov/fnic/foodcom p/cgibin/list_nut_edit.pl.

Widowati, S. 2001. Pemanfaatan Hasil Samping Penggilingan Padi Dalam Menunjang Sistem Agroindustri di Pedesaan. Bultin AgroBio 4(1): 33-38.

Widyawati, S. P., Suteja, M. A., Suseno, P. I. T., Monika, P., Saputrajaya, W., dan Liguori, C. 2014. Pengaruh Perbedaan Warna Pigmen Beras Organik Terhadap Aktivitas Antioksidan. Jurnal Agritech 34(4): 399-406.

Winarno, F.G. 2002. Kimia Pangan dan Gizi. PT Gramedia. Jakarta.

Winata, E. W. dan Yunianta. 2015. Ekstraksi Antosianin Buah Murbei (Morus alba L.) Metode Ultrasonic Bath (Kajian Waktu dan Rasio Bahan Pelarut). Jurnal Pangan dan Agroindustri 3(2): 773-783. 